\title{
離岸堤の一型式 “に型堤”
}

高隆二*·藤 井充**.田川昌 宏***

\section{1. 緒言}

海岸侵食対策として多用されている離岸堤の致命的欠 宿は開口部汀線の後退である。これは開口部からの侵入 波および堤透過波あるいは越波の平面的不均一に起因 し，堤内に水面勾配ならびに循環流を生じるためであ る。

開口部汀線の両側, すなわち, 離岸堤両端背後に一対 の突堤を設け，“に型堤”と名づけて，侵入波と透過波 (越波)を分離し，準二次元的現象に帰するならば，それ ぞれ侵食性を堆積性に転換し，離岸堤の効用を飛躍的に 高めるものと期待される。

以下, 散乱し難く, 鉛直に比して著しく低い水平透水 性を有する三脚Cブロック離岸堤の基本的性質, 堆積性 ならびに二次元性に関し検討を加えた。

\section{2. 基本的性質}

\section{(1) 安定}

フラップ型二次元造波水路（幅 $1.0 \mathrm{~m} \times$ 高さ $1.0 \mathrm{~m} \times$ 長さ $50 \mathrm{~m}$ ) に縮尺 $1 / 20$ の模型を設置した。

離岸堤の天端高 $H_{c}$ は一般に低いので越波も多く, 安 定はのり面より天端ブロックに支配される。被害率 $2 \%$ を許容するHudson 公式の意を汲んで，堤直前研波に対 し $K_{D}^{\prime}=K_{D} \cot \theta$ を指標とした転落限界は, $H_{c} / H$ の増 加とともに増大し，天端幅とは無関係である11。

\section{(2) 消 波}

砕波带内で常用される離岸堤の半波長後方において測 定した堤設置前後の波高比を伝達率とした。伝達率は， $H_{c} / H_{0}$ および $h / L_{0}$ の増加とともに減少し， $H_{0} / L_{0}$ には あまり影響を受けない(図一1)。

反射率定砕波帯内で測定するのは困難であり，その沖 側に設置すると大略 $0.2 \sim 0.4$ 程度となる1。

段積みにした三脚Cブロックの空隙は，鉛直方向には 中空部抢よび相互の間隙であるのに対し，水平方向には 細長い菱形の間隙（最小幅 $3.0 \mathrm{~mm}$ で砂粒径の 5 倍）に すぎない（写真一1）。

堤体に当る波は，越波（天端上を越して堤内に飛込

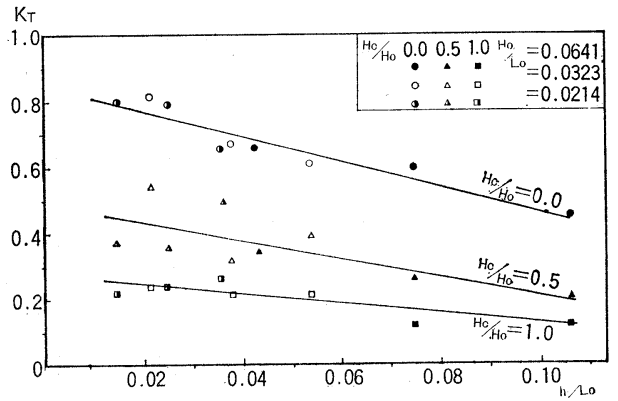

図一1 伝達率

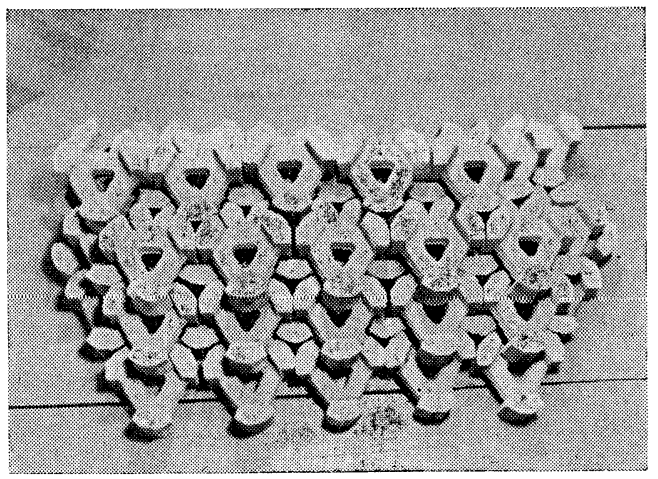

写真一1（a） 三脚Cブロック（平面）

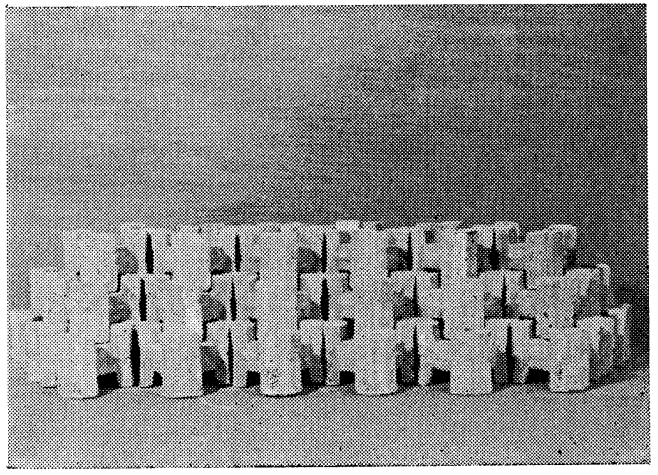

写真一1（b） 三脚Cブロック（正面）

む。 $H_{c} / H<0.8$ ), 浸透（天端上に達し, 堤体内に浸透。 $H_{c} / H=0.8 \sim 1.0$ ), あるいは透過（堤体を透過。 $H_{c} / H>$ 1.0) 乙て堤内に伝達する1)。

\section{（3）越波}

相対越波量 $2 \pi Q / H_{0} L_{0}\left(Q\right.$ : 越波量) は $H_{0} / h=0.6$ 付 
表一1 伝達波のエネルギー

\begin{tabular}{r|r|r|r|r|r|r|r|r|r|r|r}
\hline$T(\mathrm{sec})$ & $h(\mathrm{~m})$ & $h_{T}(\mathrm{~m})$ & $L_{0}(\mathrm{~m})$ & $C_{G}(\mathrm{~m} / \mathrm{sec})$ & $H_{0}(\mathrm{~m})$ & $H_{0} / L_{0}$ & $H_{I}(\mathrm{~m})$ & $H_{T}(\mathrm{~m})$ & $E_{p}\left(\mathrm{~kg} / \mathrm{sec}^{3}\right)$ & $E_{p}{ }^{\prime}\left(\mathrm{kg} / \mathrm{sec}^{3}\right)$ & $W_{w}\left(\mathrm{~kg} \cdot \mathrm{m} / \mathrm{sec}^{3}\right)$ \\
\hline \multirow{2}{*}{8.94} & 1.74 & 1.81 & 124.8 & 4.47 & 1.096 & 0.0088 & 1.016 & 0.49 & 9.01 & 5.15 & 308.97 \\
6.71 & 1.74 & 1.82 & 70.2 & 4.25 & 1.150 & 0.0152 & 1.070 & 0.36 & 6.94 & 5.01 & 110.30 \\
\hline
\end{tabular}

$\left(H_{I} ;\right.$ 入射波高, $E_{p^{\prime}}{ }^{\prime}$ 越波限界の位置エネルギー)

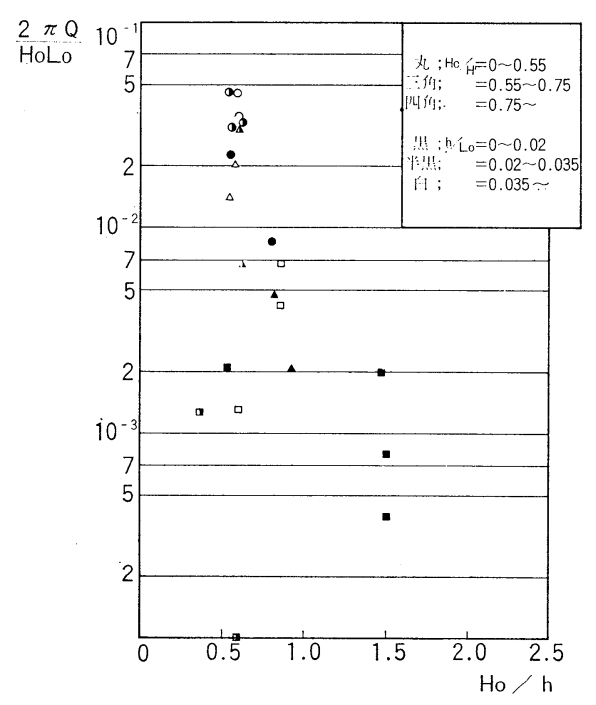

図一2 相対越波量

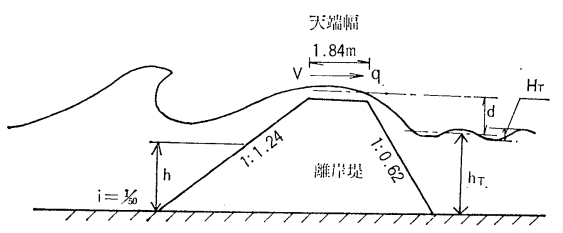

図一3 ェネルギーの伝達

近で最大, $H_{c} / H$ の増加に伴い単調に低減する(図一2)。

\section{（4）エネルギー再生率}

天端上の流速 $V$, 単位幅, 単位時間当り越波量 $q$ の水 塊は, 運動エネルギー

$$
W_{k}=\frac{1}{T} \frac{\rho}{2} \int_{0}^{\tau} q V^{2} d t
$$

と位置エネルギー

$$
W_{p}=\frac{1}{T} \rho g \int_{0}^{\tau} q \cdot d d t
$$

の和，全エネルギー

$$
W_{I}=W_{k}+W_{p}
$$

を輸送する(図一3)。ただし， $T$ ：波の周期， $\rho$ : 水の密 度, $g$ : 重力加速度, $\tau$ : 各越波の作用時間, $d$ : 堤内平 均水面上越流中心の高さである。

一方, 伝達波の位置エネルギーは、らを水位として,

$$
E_{p}=\frac{1}{T} \frac{\rho g}{2} \int_{0}^{T} \zeta^{2} d t
$$

で与えられ，運動エネルギーもこれに等しいと近似し， 一周期当り伝達波のエネルギー輸送は,

$$
W_{w}=2 E_{p} C_{G} T \text {. }
$$

となる。ただし， $C_{G}$ は波の群速度である。水位上昇 (速度 $q / L_{i}, L_{i}$ : 堤内の長さ) による一周期ごとの位置 エネルギー増加量

$$
W_{\eta}=\int_{0}^{\tau} \frac{\rho g q^{2}}{L_{i}} d t
$$

を加えると，伝達波に関しては

$$
W_{T}=W_{w}+W_{\eta}
$$

である。浮子を高速度 $8 \mathrm{~mm}$ 撮影により追跡し，伝達波 のエネルギー再生率 $W_{T} / W_{I}$ を算定すると, $0.1 \sim 0.2$ となる（図一4，表一1〜4）。ちなみに，土塊の位置エネ ルギーは地すべりにより，2\% 程度をCauchy一Poisson 波として津波エネルギーに再生させている2)。
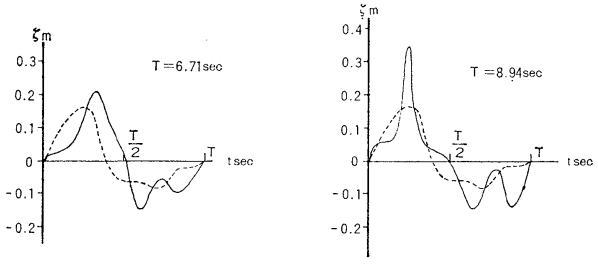

$$
\text { 一; 坫波19 }
$$

図-4 伝達波形

表一2 水位上昇のエネルギー

\begin{tabular}{c|c|c|c|c}
\hline$T(\mathrm{sec})$ & $L_{i}(\mathrm{~m})$ & $\tau(\mathrm{sec})$ & $q\left(\mathrm{~m}^{2} / \mathrm{sec}\right)$ & $W_{\eta}\left(\mathrm{kg} \cdot \mathrm{m} / \mathrm{sec}^{3}\right)$ \\
\hline 8.94 & 100 & 1.74 & 0.272 & 6.16 \\
6.71 & 100 & 1.07 & 0.292 & 5.98 \\
\hline
\end{tabular}

\section{（5）水位上昇}

$h / h_{b}=0.7$ の地点 $(h:$ 測定水深) で測った砕波帯内の 水位上昇 $\eta$ は, 移動床のため海底变動を生じており, 固定床に適用される3)

$$
\left.\begin{array}{l}
\frac{\eta}{h_{b}}=\sqrt{1+\frac{32 K H_{b}}{3 g T_{b}^{2}}}-1 \\
K=3 \sim 5
\end{array}\right\}
$$

において，K=2.57 とおくとよい(図一5)。

堤設置後, 単位幅, 単位時間当り堤内に侵入および堤 外に排出する水塊の容積をそれぞれ $q, q_{0}$ 堤内水位を $\eta_{i}$ 
表一3 越波エネルギー

\begin{tabular}{c|c|c|c|c|c|c|c|c|c}
\hline$T(\mathrm{sec})$ & $h_{b}(\mathrm{~m})$ & $V_{b}(\mathrm{~m} / \mathrm{sec})$ & $V(\mathrm{~m} / \mathrm{sec})$ & $q\left(\mathrm{~m}^{2} / \mathrm{sec}\right)$ & $\tau(\mathrm{sec})$ & $d(\mathrm{~m})$ & $W_{k}\left(\mathrm{~kg} \cdot \mathrm{m} / \mathrm{sec}^{3}\right)$ & $W_{p}\left(\mathrm{~kg} \cdot \mathrm{m} / \mathrm{sec}^{3}\right)$ & $W_{I}\left(\mathrm{~kg} \cdot \mathrm{m} / \mathrm{sec}^{3}\right)$ \\
\hline \multirow{2}{*}{8.94} & 2.00 & 5.40 & 4.74 & 0.272 & 1.74 & 0.56 & 1193.21 & 292.45 & 1485.66 \\
6.71 & 1.90 & 5.07 & 3.46 & 0.292 & 1.07 & 0.55 & 559.78 & 252.73 & 812.52 \\
\hline
\end{tabular}

$\left(V_{b} ;\right.$ 碎波流速)

表一4 エネルギー再生率

\begin{tabular}{c|c|c|c}
\hline$T(\mathrm{sec})$ & $W_{w} / W_{\boldsymbol{I}}$ & $W_{\eta} / W_{\boldsymbol{I}}$ & $W_{T} / W_{\boldsymbol{I}}$ \\
\hline 8.94 & 0.208 & 0.004 & 0.212 \\
6.71 & 0.136 & 0.007 & 0.143 \\
\hline
\end{tabular}

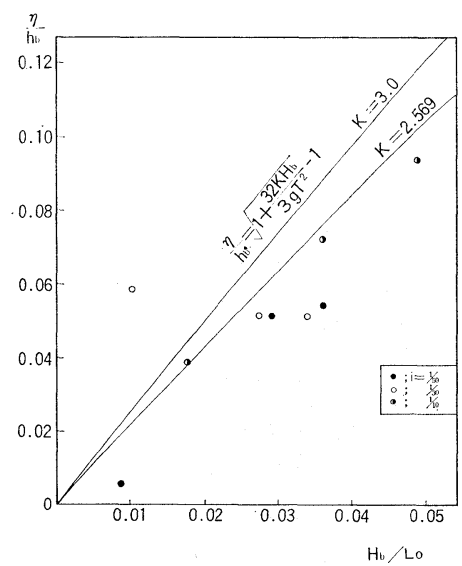

図一5 砕波後の水位上昇

とすると，連続方程式は

$$
L_{i} \frac{d \eta_{i}}{d t}=q-q_{0}
$$

となり, 排出量 $q_{0}=\frac{k h}{b} \eta_{i}(b:$ 水中平均堤体幅, $k:$ 透 水係数）学代入すると，

$$
\frac{d \eta_{i}}{d t}=\frac{q}{L_{i}}-\frac{k h}{b L_{i}} \eta_{i}
$$

となる。この式の解は

$$
\eta_{i}=\frac{b q}{k h}\left\{1-\exp \left(-\frac{k h}{L_{i} b} t\right)\right\}
$$

と求められる。固定床では約 $70 T$ ( $T$ : 周期), 移動床 では 100 150T 時間経過後, 平衡水位

$$
\left.\begin{array}{l}
\frac{\eta_{i}}{H_{0}}=\frac{H_{0}}{h} \frac{q^{\prime} b}{2 \pi k} / H_{0} / L_{0} \\
q^{\prime}=\frac{2 \pi q}{H_{0} L_{0}}=\frac{2 \pi Q}{H_{0} L_{0} T}
\end{array}\right\}
$$

に達する。

$q$ および $\eta_{i} / H_{0}$ は $H_{c} / H$ の関数であり ${ }^{1)}$, 式 (10) に より $k=5.0 \mathrm{~cm} / \mathrm{sec}$ (模型), $20 \mathrm{~cm} / \mathrm{sec}$ (現地)となる(図 一6)。 $q^{\prime}$ を読み取り， $\eta_{i} / H_{0}$ の実験値を式 (11) の計算 值と比較した（図一7）。

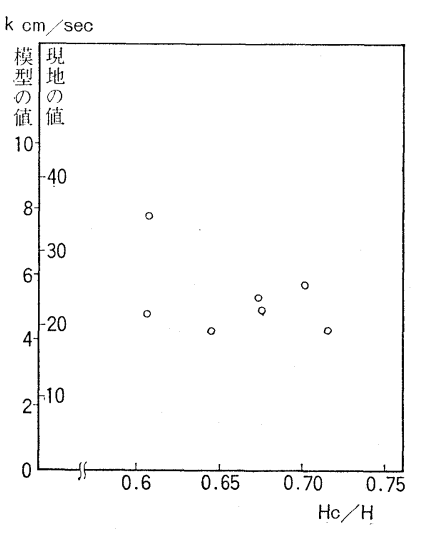

図一6 透水係数

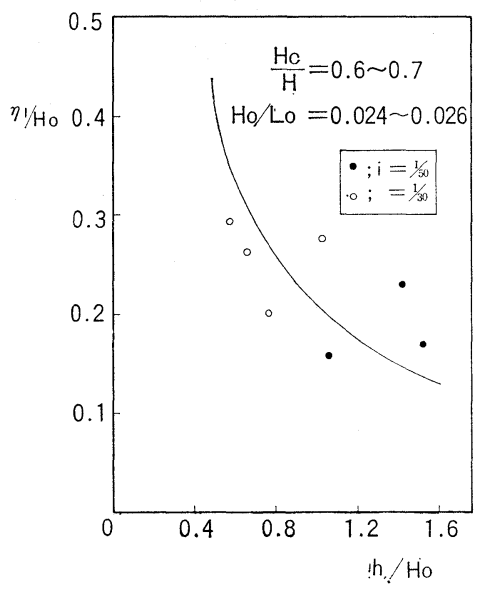

図一7堤内水位上昇

\section{3. 堆 積 性}

\section{(1) 堤設置前}

底質として, 中央粒径 $0.6 \mathrm{~mm}$ の砂を厚さ $10 \mathrm{~cm}$ に 敷いた。相似則不明のため縮尺は特に定めない。

海底砂の動きを, 砂粒に関する抵抗モーメントを上回 る全流体力モーメントによって起こり静止位置周辺をわ ずかに振動する初期運動と, 砂粒に働く全力の海底面に 平行な成分の不均衡により方向性をもって移動する確定 移動に分類する。各限界は

$$
\begin{gathered}
\beta D=\left\{6.62 \frac{S_{f}}{S_{s}-S_{f}} \frac{f_{1}\left(h_{e} / L_{0}\right)}{\sin \theta}\left(\frac{H_{0}}{L_{0}}\right)^{2}\right\}^{7 / 6} \\
\ldots \ldots \ldots \ldots \ldots \ldots \ldots \ldots \ldots \ldots \ldots \ldots \ldots \ldots \ldots \ldots \ldots \ldots \ldots \ldots \ldots \ldots \ldots \ldots \\
\beta D=
\end{gathered}
$$




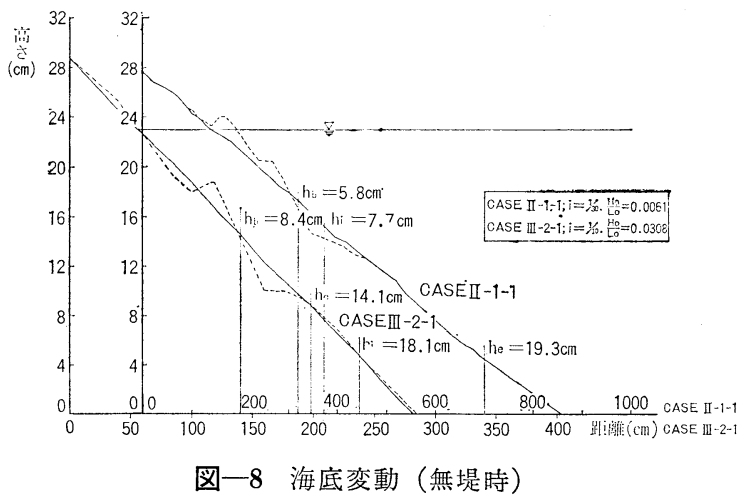

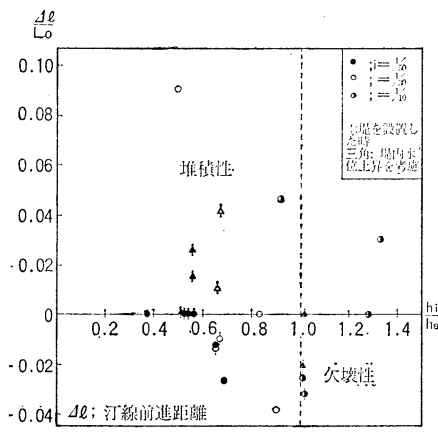

図一9 汀線変化量
で与えられ， $h_{i}>h_{e}$ では bar 崖形成し汀線は侵食され， $h_{i}<h_{e}$ は堆積性と対応するとされる4)。

ここで, $h_{i}$ : 初期運動の起こり始める水深, $h_{e}$ : 確定 移動の起こり始める水深， $D$ : 砂粒径であり，また

$$
\begin{aligned}
& f_{1}\left(\frac{h}{L_{0}}\right)=\frac{\operatorname{coth}^{2} k h}{\sinh ^{2} k h+k_{0} h} \\
& f_{2}\left(\frac{h}{L_{0}}\right)=\sqrt{k h \tanh ^{2} k h+\sinh ^{2} k h \tanh ^{2} k h} \\
& \beta=\sqrt{\frac{\pi}{\nu T}}
\end{aligned}
$$

である。ただし, $S_{s}$ : 砂の比重, $k=2 \pi / L, k_{0}=2 \pi / L_{0}$ である。

汀線不動および前進状況を, $h_{b}, h_{i}, h_{e}$ 等とともに図一 8 に例示守る。

堆積性に関する底質粒径の相似は, 式(12), (13)から

$$
\beta D=\text { const. }
$$

とすれば保たれる。したがって粒径縮尺 $D^{*}$ は

$$
D^{*}=l^{* 1 / 4}=L_{0} * 1 / 4
$$

と示される (ただし， $l^{*}$ : 幾何縮尺)。

平衡状態における $h_{i} / h_{e}$ は, 波の作用時間 3 時間後の 堆積侵食をかなり定量的に説 明する有力な指標である（図 -9)。

他方, 波の作用時間 20 時 間以上, 海底勾配 $i=1 / 30 \sim$ $1 / 20$, 粒径 $d=0.2 \sim 0.3 \mathrm{~mm}$ の範囲で行われた模型上の限 界も表示されている5（図一 10)。一方, 同じ $H_{0} / L_{0}$ に対 し $d / L_{0}$ の縮尺はほぼ $1 / 10$ と なる。一般に 1/20～1/30 前 後である幾何縮尺に対し, 粒 径縮尺は $1 / 2 \sim 1 / 3$ となる。 式（14）より求めた $1 / 2.11 〜$
1/2.34はこれと近く，堆積性に関する底質の相似を表わ す模様である。

\section{（2）堤設置後}

侵食性海岸の砕波帯内に離岸堤を設置し，その効果を 堤内水容積 $W$ の設置後減少量 $\Delta W$ 及び汀線前進量 $\Delta l^{\prime}$ で表わした（図一11）。砂は常に堤内に舞込み，汀線は $h / h_{b}=0.5 \sim 1.0$ ( $h$ : 堤設置水深) で前進。それ以浅では かえって侵食を助長する（図一12１4）。

統一的に取扱うため, 設置後は換算沖波波高 $H_{0}{ }^{\prime}=H_{0}$. $K_{T}\left(K_{T}\right.$ : 伝達率 $)$ を用い, 図一9, 10 に併記した。こ れは静水時の汀線に対し適合しない。しかし，堤設置後 には水位上昇をきたして抢り，その高さの汀線の前進後 退を表現している。

\section{(3) 堤の沈下}

沈下に関する相似則は明らかでない。模型では，離岸 堤の有効な $h / h_{b}=0.5 \sim 1.0$ の範囲で, 沈下は著しく, 堤内側に傾く（図-15）。

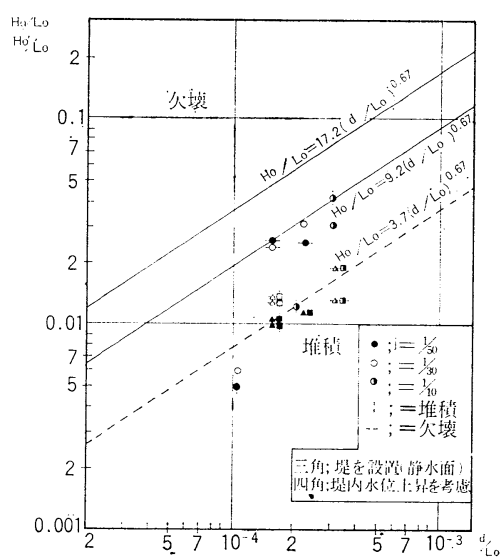

図一10 汀線变化

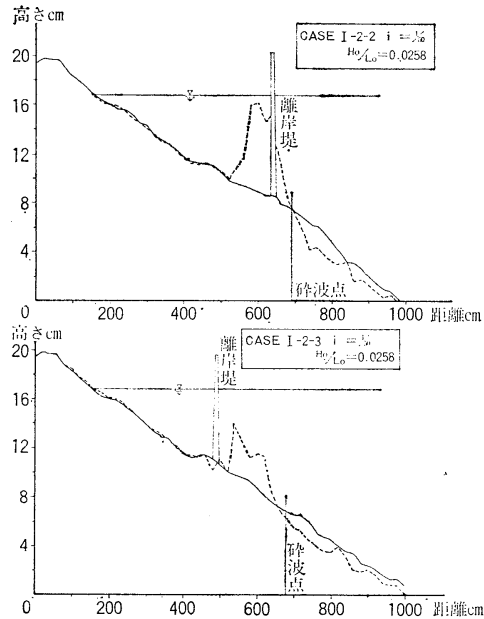

図一11 海底変動（堤設置） 


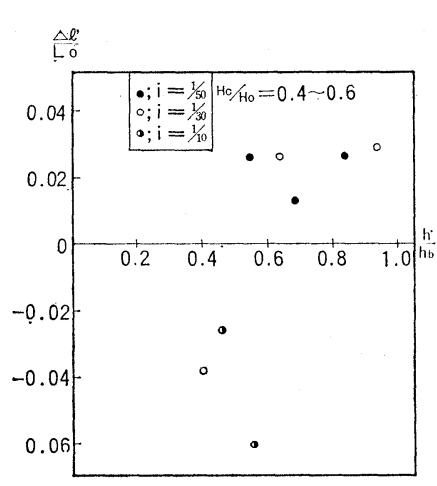

図一12 汀線前進量

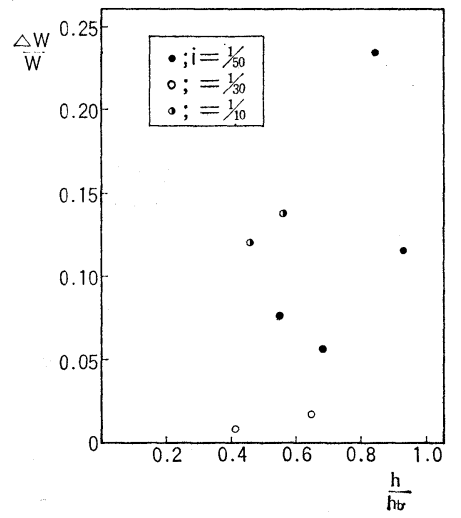

図-13 堤内堆積量

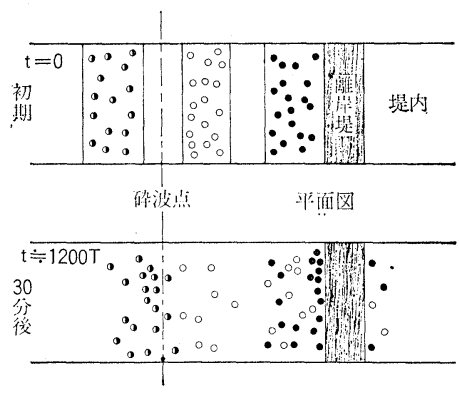

図-14 砂の移動

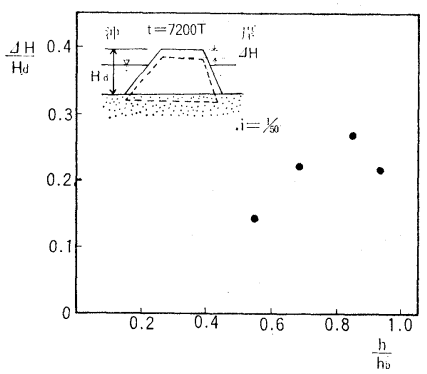

図一15 沈下 量

\section{4. 二次元性}

(1) 概 要

縮尺 1/40, 図一16 の断面を持つ離岸堤を表一5 のよ うに平面的に配置し, 波高, 水位および流速の分布を固 定床上で測定した。波高 $1.6 \mathrm{~m}$, 周期 $6.0 \mathrm{sec}$ の実験波 は，底質粒径 $0.4 \mathrm{~mm}$ 以下では侵食性である5)。

\section{(2) 結果}

a) 波 高

平面的分布を図一17 (a ) (d) に示す。図-18 (a), （b）に堤中央部および開口部線上の波高を比較する。

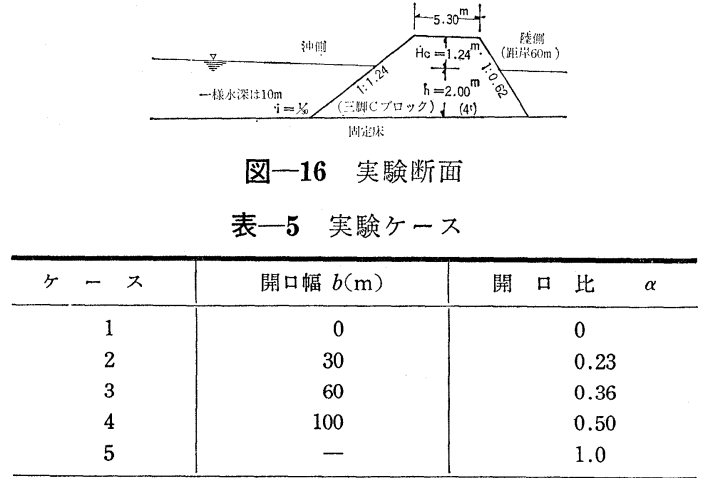

$(\alpha=b / l+b$, 堤長 $l=100 \mathrm{~m}$, 距岸 $60 \mathrm{~m})$

$H_{0} / L_{0}=0.0285, i=1 / 30$ の無堤時に打いて, 距岸 $60 \mathrm{~m}$, $h_{b}=2.3 \mathrm{~m}, H_{b}=1.9 \mathrm{~m}$ で巻き波状に砕け6)，砕波の持続 距離は約 $20 \mathrm{~m}$ (1.2 波長) となる。碀波後の減衰状況 ${ }^{3)}$ は，

$$
\begin{aligned}
& \left.\frac{H}{H_{b}}=\frac{h}{h_{b}} \exp \left\{-c\left(1-\frac{h}{h_{b}}\right)\right\}\right\} . \\
& c=1.5
\end{aligned}
$$

と表わせる。堤設置後, $H_{b}=2.2 \mathrm{~m} \sim 2.6 \mathrm{~m}, h_{b}=2.6 \mathrm{~m}$ 前後となり, 開口部からの進入波は中央部の伝達波より

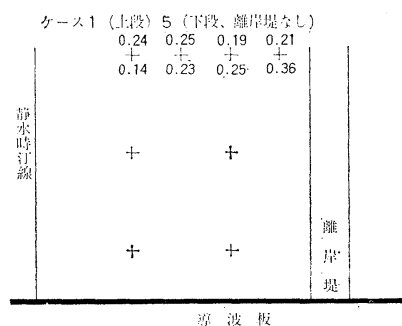

図一-17（a）堤内波高比

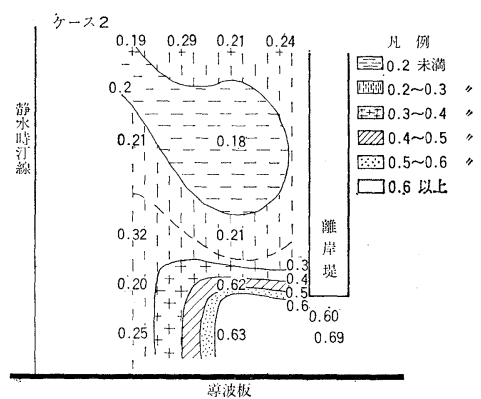

図-17(b)

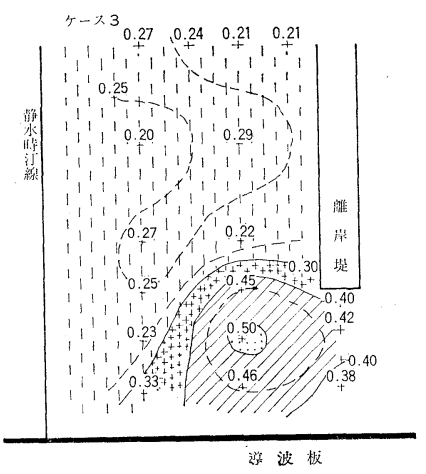

図-17(c) 


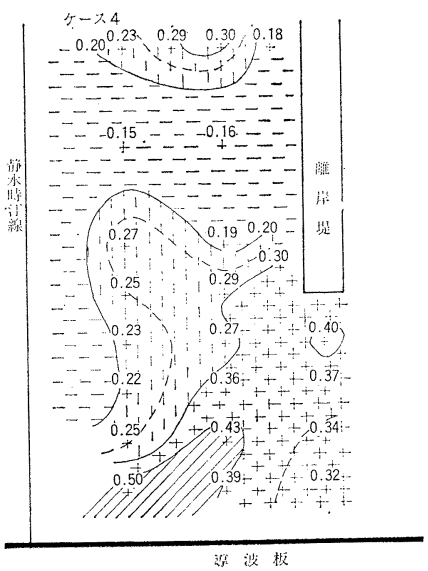

図-17(d)

高く，汀線に接近しても減衰は著しくない。

b) 水 位

無堤時の水面勾配は一様で，radiation stress を用いて 算定した砕波点における wave set down および硴波帯 における wave set up と比較した（図一19(a)〜 (d))。 連続堤内の水位は漸増し, $70 T$ 前後で平衡に達し, 無 堤時には $30 T$ で一応平衡となる。開口部を設けると，

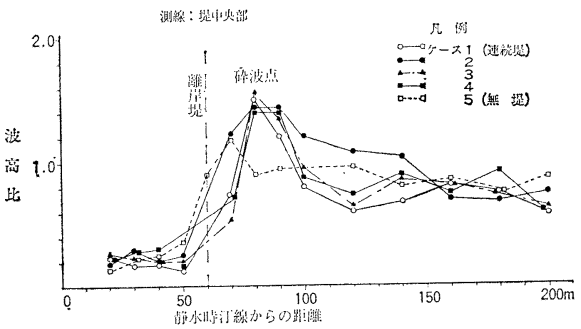

図一18（a）離岸堤直角方向の波高比

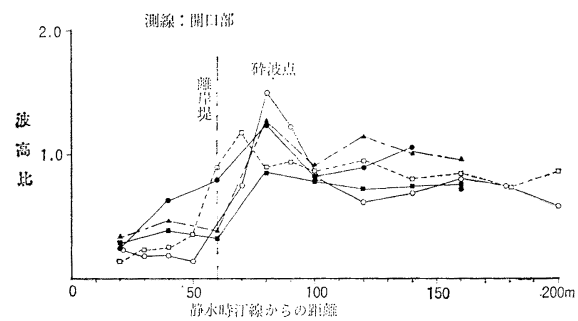

図一18（b)

$40 T$ 程度で卓越した侵入波により最高水位を記録した 後，越波も含めた平衡水位まで漸減する(図一20)。平衡 水位は時間的変化を反映して，開口比により極大，極小 它有する（図一21）。

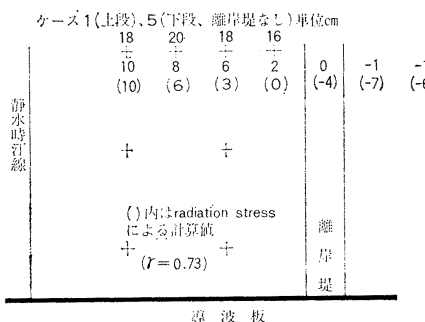

図-19（a）堤内水位

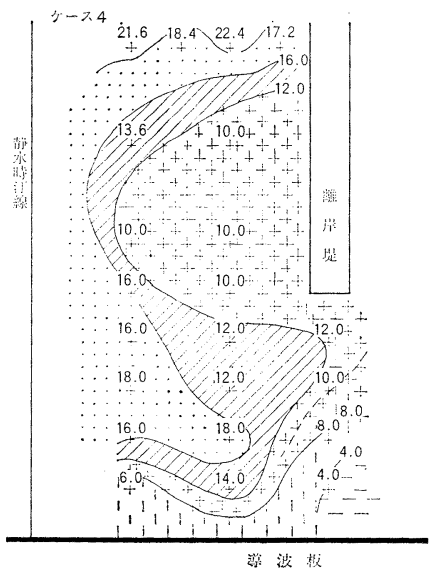

図-19(d)

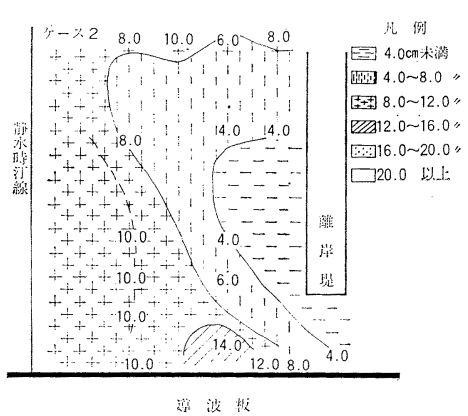

図-19(b)

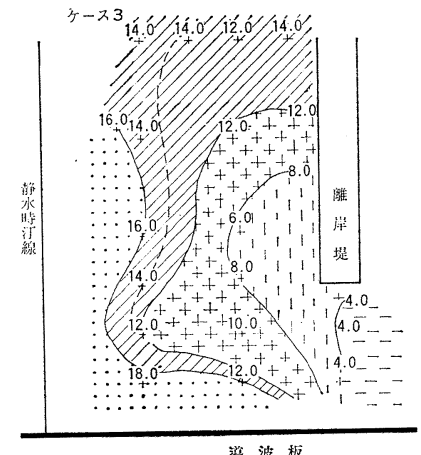

図-19(c)

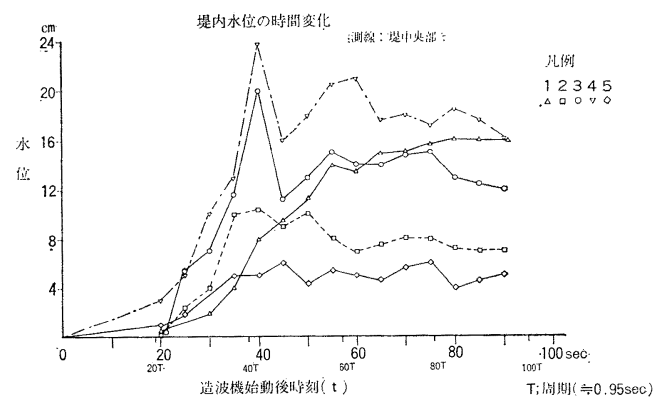

図一20 堤内水位の時間变化 


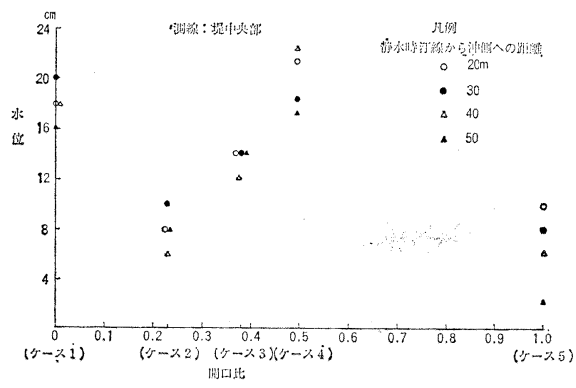

図一21 堤内水位と開口比

c) 流 速

開口部の流向は, 当初侵入波の卓越により岸向き，平 衡に達した後侵入波と越波の質量輸送の補流として沖向 きとなる。

欠壊を誘起する汀線沿いの流れは, 最大流速約 $2.0 \mathrm{~m} /$ $\sec$ に達し, 開口部から中央部に向う。堤背後では逆向 する(図-22(a)〜 (c))。

\section{(3) 対 策}

開口部汀線に沿った流れの比較的遅い Case 3 におい て, 対策として副離岸堤を設けると, 開口部汀線は守ら れても, 中央部汀線付近に沿う流れを発達させる（図一 23 (a))。

一方, 突堤は開口部からの侵入波の大勢を伝達波と分 離し，堤内循環流它有効に分断する（図一 $23(\mathrm{~b}))$ 。

\section{5. 結言}

radiation stress は, 通常砕波帯内に設けられる離岸堤 内の波高, 水位, 流速および摩擦を関連させ，汀線沿い に一様であれば局部的な堆積侵食を生じない。

しかし，流速は時には波速を越え，また砂移動および 摩擦に関する相似も十分解明されてない移動床模型に頼 ること学避け，固定床上の測定結果のみ列記した。

開口部から同心円状に伝わる侵入波峰它難透水性の三 脚 Cブロック突堤は沿い波として加速し，直線化すると そもに，その両側で差異を生じ radiation stress に基づ く堤透過流を阻止する。侵入波と伝達波を比較的短い突 堤で分断し，両者を堆積性とする一型式を提案する次第 である。

\section{参考文 献}

1）日本港湾コンサルタント：離岸堤の研究，1974.

2) 三好 寿：波・津波，河出書房，1971.

3）中村 充・白石英彦・佐々木泰雄：碎波による水 理特性，第 15 回海岸工学講演会講演集，1968.

4) 井島武士：海岸工学, 朝倉書店, 1970 .

5）堀川清司・砂村継夫・鬼頭平三：波による海底変 形に関する一考察，第 20 回海岸工学講演会論文 集，1973.

6）井島武土：海岸港湾測量，森北出版，1960.

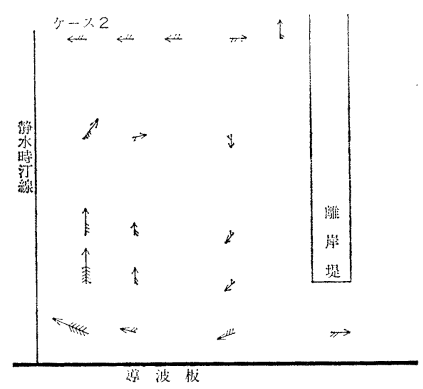

図一22 (a) 堤内流況

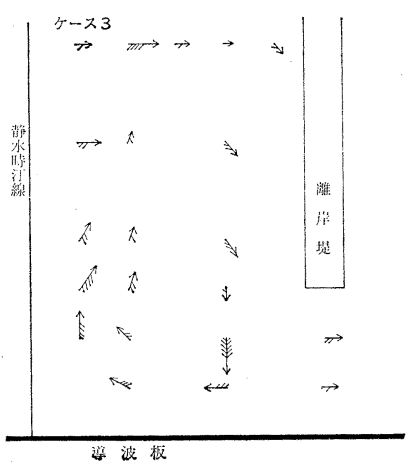

図-22(b)

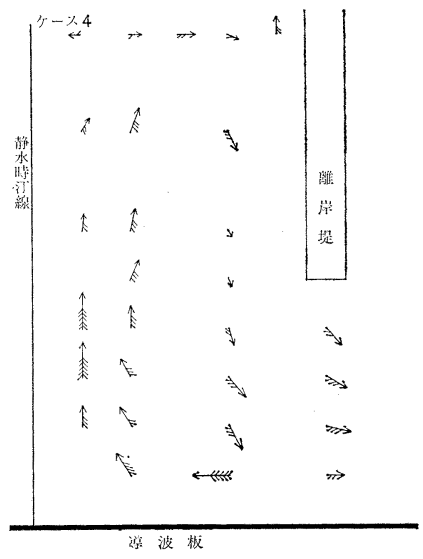

図-22(c)
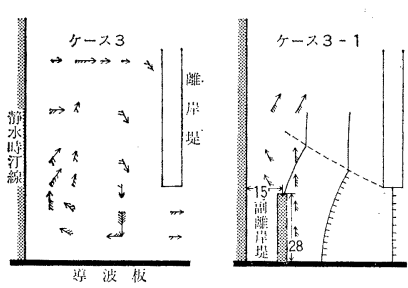

図-2

$$
\text { 凡例 }
$$

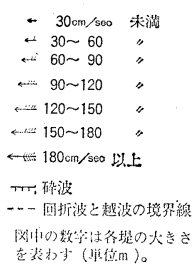

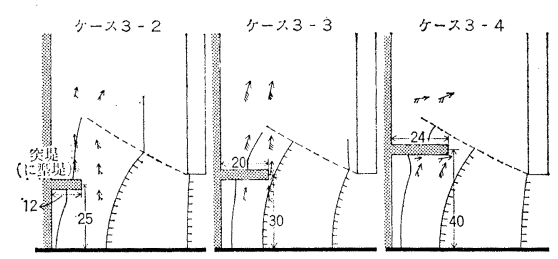

図-23(b) 